\title{
Taxonomy and typification of Kalanchoe olivacea and K. bhidei (Crassulaceae)
}

\author{
Mayur D. Nandikar ${ }^{*}$, Rohini A. Shinde² \& Henry J. Noltie ${ }^{3}$ \\ ${ }^{1}$ Naoroji Godrej Centre for Plant Research (NGCPR), 431, Lawkim Campus, Shindewadi, Shirwal, Satara distritct, Maharashtra - 412 801, India. \\ ${ }^{2}$ Department of Botany, Yashavantrao Chavan Institute of Science, Satara district, Maharashtra - 415001 , India. \\ ${ }^{3}$ Royal Botanic Garden Edinburgh, 20A Inverleith Row, Edinburgh, EH3 5LR, United Kingdom. \\ *Email: mnandikar@gmail.com
}

\begin{abstract}
A synopsis of Kalanchoe olivacea Dalzell and K. bhidei T.Cooke (Crassulaceae), both endemic to Peninsular India, is presented, together with morphological descriptions and photographs. The study is based on an examination of living and herbarium collections; it includes updated nomenclature, typification, and notes on distribution and conservation status. In both cases the original material is ambiguous. In the case of $K$. olivacea the original drawing does not show one of the diagnostic characters and in the case of $K$. bhide $i$ the single surviving syntype is in extremely poor condition. So, in both cases typification requires the designation of a lectotype and an epitype.
\end{abstract}

Keywords: Crassulaceae, Endemic, India, Kalanchoe, Taxonomy, Typification.

\section{Introduction}

Kalanchoe olivacea Dalzell is endemic to the Western Ghats of India. It was first collected by Alexander Gibson from an unrecorded locality and by N.A. Dalzell soon thereafter. Dalzell described the species from Pandooghur, under the cliff of Panchgani (Dalzell \& Gibson, 1861), based on characters including the olive-coloured leaves dotted with blood-red and flowers clothed with glandular viscid hairs. Prior to its description the only glandular-hairy flowered species known in India were $K$. glandulosa Hochst. (distinguished by its branched panicles and tubular calyx) and K. floribunda Wight \& Arn. (with yellow flowers). Until the publication of Cooke (1903) $K$. olivacea was little known or misunderstood as it was not treated by Clarke (1878), although it was included on an erratum slip present in some

Received: 30.8.2018; Revised \& Accepted: 20.05.2019 Published Online: 30.09.2019 copies of that work, where it was stated to be a synonym of what (based on Ritchie's specimens) Clarke had referred to K. brasiliensis Camb. [ $=K$. crenata (Andrews) Haw.] However, that species (Cambessèdes, 1830), while sharing the characters of glandular inflorescence and acuminate corolla lobes, differs in having rose-red flowers. Kalanchoe olivacea was omitted from the original edition of Index Kewensis, though included in its third supplement (1908). Cooke (1903), who attributed its overlooked status to having been published in the 'Addenda et Corrigenda' section of Dalzell's and Gibson's Bombay Flora, reinstated $K$. olivacea and distinguished it from rather similar collections from Shirgaon Ghat (about $27 \mathrm{~km}$ from Panchgani), but with glabrous flowers, which he described as the new species $K$. bhidei. Although both have subsequently been recognized by Gamble (1919), Gandhi (1976), Rao and Razi (1981), Srinivasan (1983), Sharma et al. (1984), Rao (1984), Godbole and Das (2000), Descoings (2003) and Singh et al. (2011), all appear to have followed Cooke (1903) and distinguished the pair of species merely on flower colour and presence or absence of hairs.

In the course of an investigation of the species of flowering plant described by N.A. Dalzell, the authors have had the opportunity to collect $K$. olivacea as its type locality Panchgani, and to visit Shirgaon Ghat, the type locality of K. bhidei. Several additional localities for both species have been identified in Maharashtra, where collections were made and photographs taken. As the taxonomic status of both species is given as 'unresolved' in The Plant List (2013), the intention of the present work is to provide more complete descriptions of both species. 
Besides studying the plants in the wild the authors consulted the Indian herbaria BSI, BLAT, CAL, $\mathrm{JCB}, \mathrm{MH}$ and $\mathrm{K}$, in order to find original material, and to obtain information on the distribution of the species. However, only a handful of extant specimens, most are fragmented and in poor condition. The type locality given in the protologue of $K$. olivacea is 'Pandooghur, under the cliff of Paunchgunny'. Searches of the herbaria $\mathrm{K}, \mathrm{CAL}, \mathrm{DD}$ and $\mathrm{W}$, where Dalzell collections are known to have been deposited (Stafleu \& Cowan, 1976), failed to locate any specimen referable to $K$. olivacea.

In a book on the Dapuri botanical drawings, Noltie (2002) reproduced a drawing of K. olivacea annotated by Alexander Gibson 'Kalanchoe new species very rare', and by Dalzell with his binomial. Noltie stated that as 'there is no Dalzell specimen at K [the location of Dalzell's top set of specimens], CAL, DD and W there is thus a strong case for making this...... drawing the type of the species'. The drawing was made either between November 1847 and October 1848, or between March 1849 and April 1850 and represents a specimen cultivated in the Dapuri Botanic Garden collected (from an unrecorded locality) by Gibson, who, from his annotation, recognized it to be an undescribed species. Although Gibson and Dalzell did not have particularly good personal relations, they collaborated over the authorship of the Bombay Flora and in 1868, on Gibson's retirement, Dalzell succeeded to his post as Director of the Bombay botanic gardens and Conservator of Forests. The date of Dalzell's annotation of the drawing is not known, but as it bears the name in his handwriting it can be considered original material, despite not showing one of the plant's diagnostic characters the glandular hairs on the inflorescence. Although the Dapuri artist was very strong on draftsmanship and sense of design, his limited ability to depict fine details such as hairs is apparent in several of the drawings in the collection, as noted by Noltie (2002), e.g. Cissus repanda Vahl (p. 98) and Portulaca grandiflora Hook. (p. 189). Despite the limitations of the drawing we below formally designate it as lectotype (Art. 9.3 of ICN, Turland et al., 2018), but with a supporting epitype (Art. 9.9 of ICN, Turland et al., l.c.), a Bhide collection of K. olivacea from the type locality.
A search has been made for original material of $K$. bhidei at BSI, CAL and IH (now amalgamated with HAC). At BSI are numerous specimens of $K$. olivacea collected by R.K. Bhide and annotated by T. Cooke, although all in poor condition, but no original specimens of $K$. bhidei could be located. However, at BLAT a single specimen collected by Bhide at Shirgaon Ghat was found; this was mentioned by Almeida (1998) and bears a stamp that shows it to have been transferred to BLAT from BNHS. The specimen label is written in Cooke's hand, giving the binomial and the same locality, date and collector as in the protologue. Although there is no collector's number, it may well be a duplicate of the number (1243) given in the protologue, as believed by whoever added the recent label with the annotation 'para-type, no. 1243 '. It appears to be a syntype and adequate for lectotypification (Art. 9.3 of ICN, Turland et al., l.c.); however, due to its poor condition, it is of little use in helping with the precise application of the name $K$. bhidei, so to avoid taxonomic ambiguity, a recent collection of $K$. bhidei from the type locality is designated here as epitype (Art. 9.9 of ICN, Turland et al., l.c.).

\section{Taxonomy}

Kalanchoe olivacea Dalzell in Dalzell \& Gibson, Bombay Fl. 313. 1861. Lectotype (designated here): Dapuri Drawing, no. 34, collection of the Royal Botanic Garden Edinburgh (reproduced in Noltie, 2002). Epitype (designated here): INDIA, Maharashtra, Satara, Panchgani (along the cliff above the Bazar), 16.11.1902, R.K. Bhide 1067 (K, $\mathrm{K} 001325248$ !; iso BSI!).

Figs. 1-3

Erect to decumbent, perennial, succulent, green to olive (turning chestnut) at maturity, tufted herb. Stems 15 to $60 \mathrm{~cm}$ tall, jointed, glabrous, internodes and nodes distinct. Leaves caducous (fallen by fruiting stage), decussate, proximal leaves subsessile, distal sessile; lamina ovate to lanceolate, or oblanceolate, $1-10 \times 0.5-4 \mathrm{~cm}$, succulent, reduplicate, or often conduplicate, glabrous, olive to khaki or peach to terracotta, base cuneate to attenuate, margins usually crenate, distal leaves crenate to dentate to entire, apex acute to obtuse. Inflorescence terminal or supra-axillary of 3-6 compound cymes; cymes 2-4-flowered, 4-5(-7) $\mathrm{cm}$ long; peduncles $0.2-1.5 \mathrm{~cm}$ long, glandular hairy, olive to vinaceous, bracteate; bracts fleshy, 

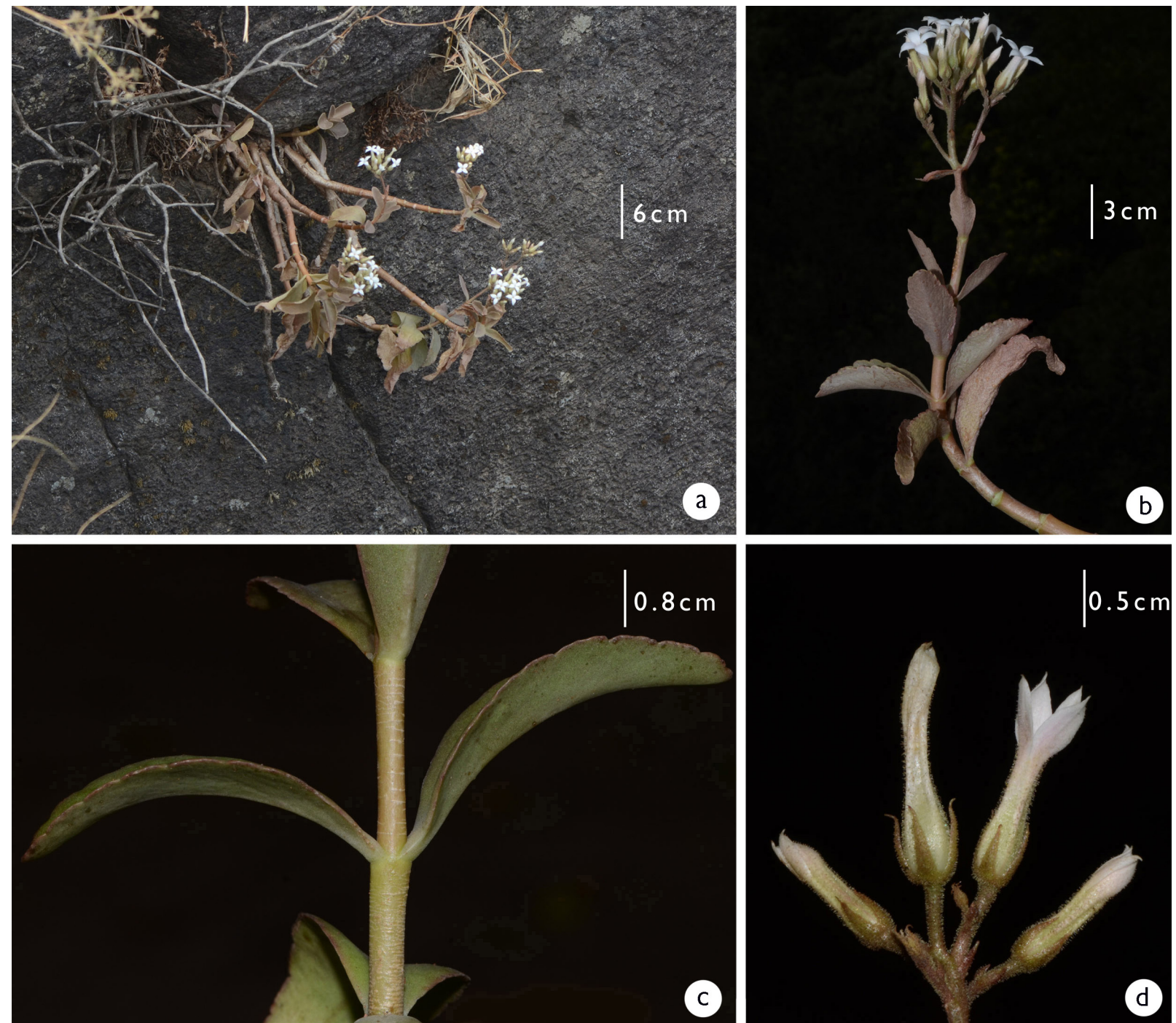

C)
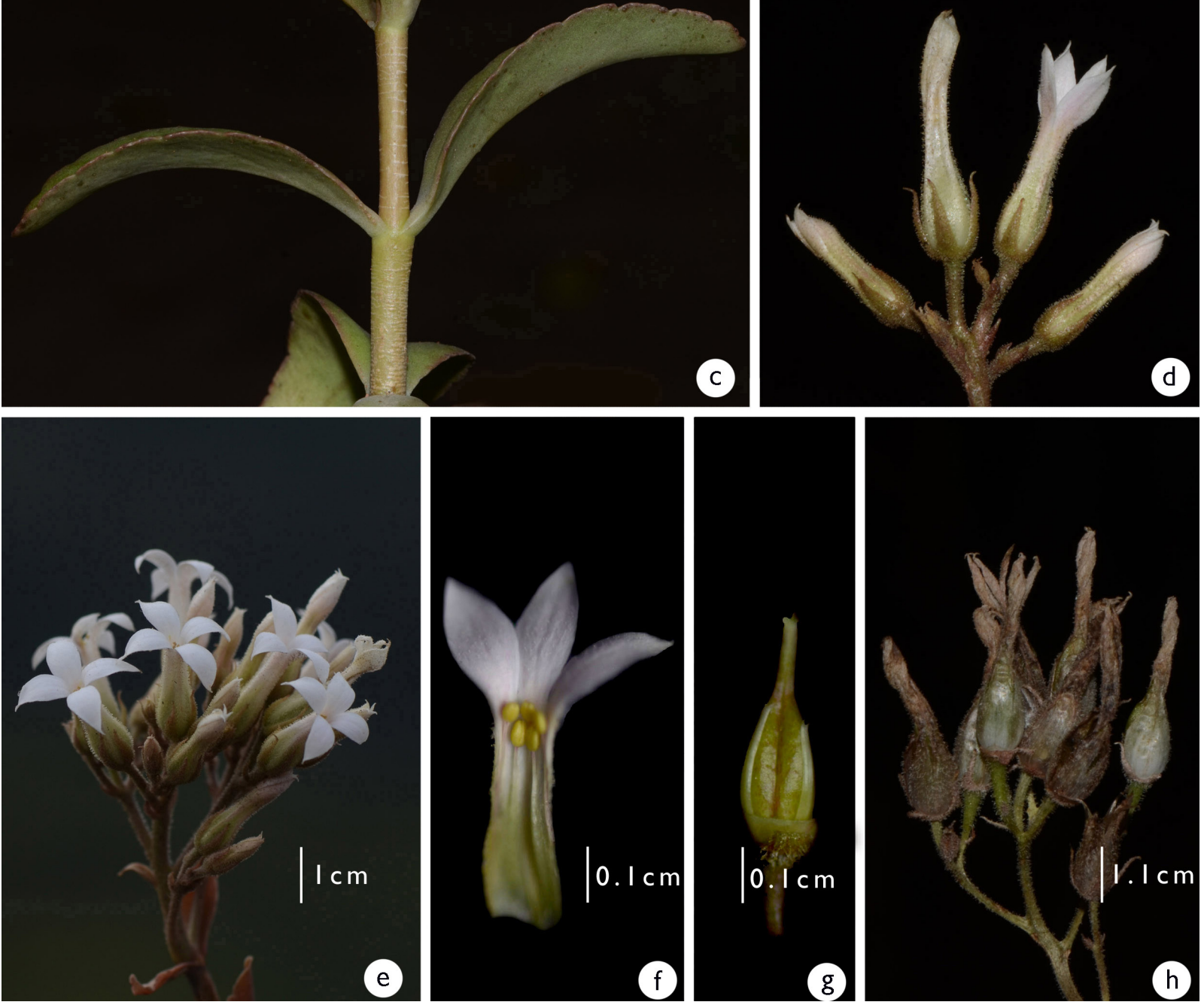

Fig. 1. Kalanchoe olivacea Dalzell a. Habitat; b. Habit; c. Leaves; d. Inflorescence; e. Flowers; f. Dissected flower with obdiplostemonous stamens: $\mathbf{g}$. Pistils with linear nectar scales; h. Infructescence (Photographs: Mayur D. Nandikar). 


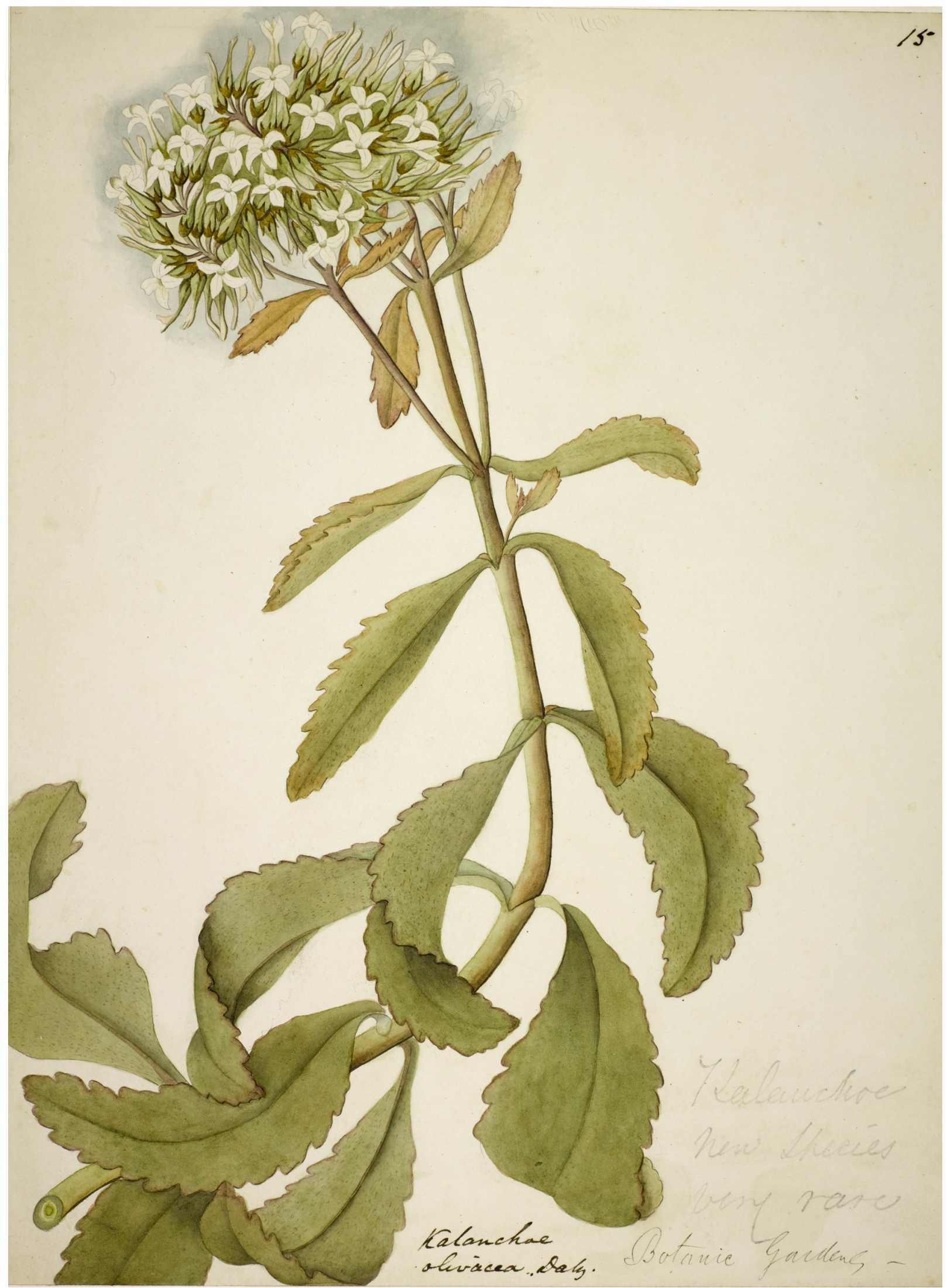

Fig. 2. Drawing of Kalanchoe olivacea with Dalzell's annotation bottom centre, and Gibson's bottom right, designated here as Lectotype (Royal Botanic Garden Edinburgh). 
Mayur D. Nandikar et al. 201

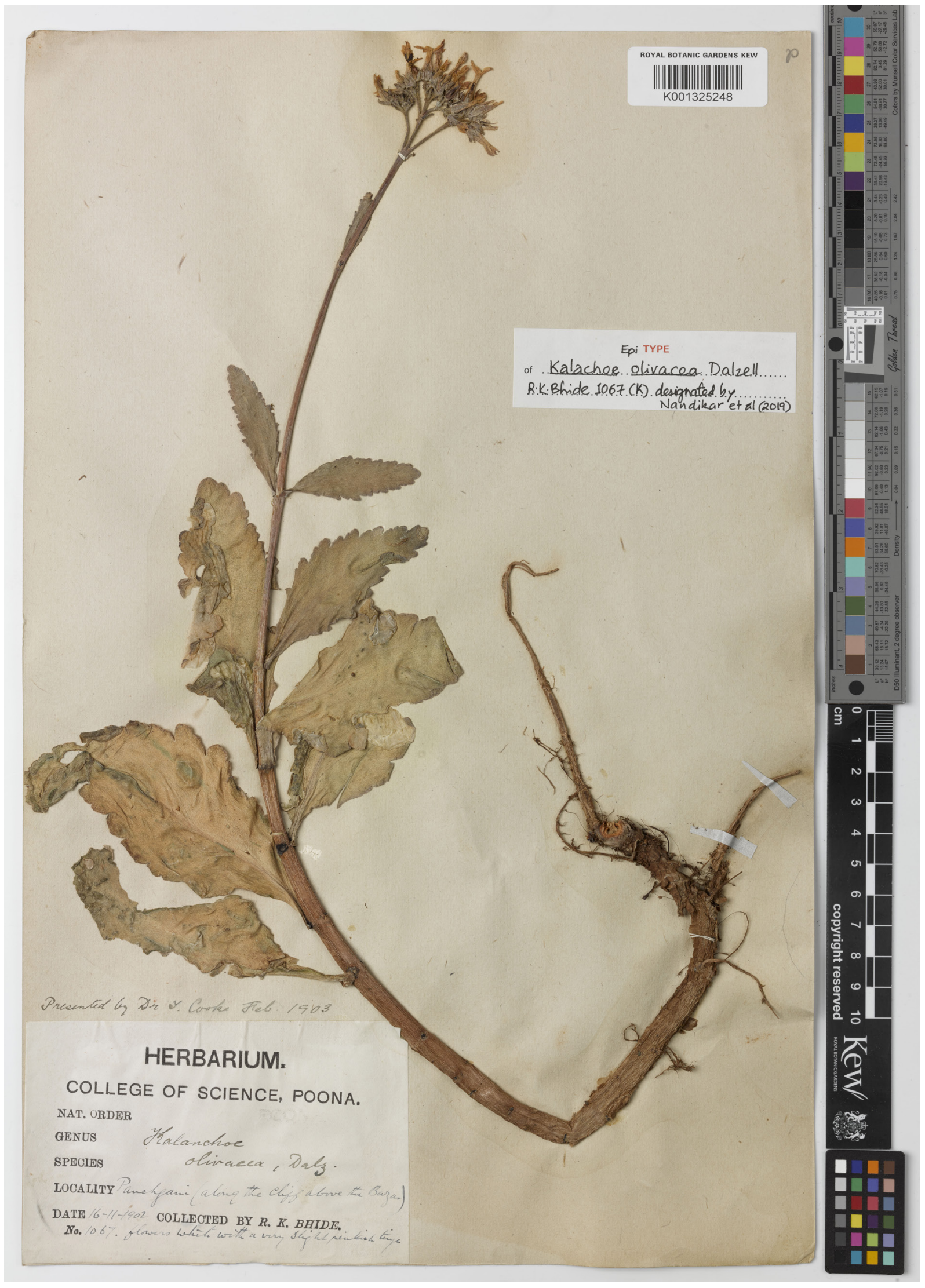

Fig. 3. Epitype of Kalanchoe olivacea Dalzell (K001325248) [C The Board of Trustees of the Royal Botanic Gardens, Kew]. 
supra-axillary, lanceolate to falcate, c. $0.2 \times 0.5 \mathrm{~cm}$, vinaceous, glandular hairy; bracteoles similar to bracts, occasionally subulate, occasionally adhering to small, underdeveloped flowers. Flowers erect, pedicellate; pedicels $0.5-0.7(-1) \mathrm{cm}$ long, glandular hairy, olive to vinaceous, buds obpyriform to pandurate. Calyx lobes free (fused inconspicuously at base), lanceolate, equal, c. $0.6 \times 0.2 \mathrm{~cm}$, apex acuminate, usually outwardly curved, densely glandular hairy, pink to fawn or olive. Corolla $1.7-2 \mathrm{~cm}$ long, densely to sparsely glandular hairy without, sparsely hairy within (at least at lobes); tube obpyriform, $1.2-1.5 \mathrm{~cm}$ long, angularfluted, streaked with green, pink and white; lobes white, spreading, lanceolate, c. $0.5 \times 0.3 \mathrm{~cm}$, acuminate to caudate. Stamens 8, 2-rowed, slightly obdiplostemonous, the longer antipetalous, 1.2$1.6 \mathrm{~cm}$ long, included in corolla tube, the shorter between the lobes, $0.8-1.2 \mathrm{~cm}$ long; filaments adherent to the corolla tube, free at $1 / 3$ part, filiform, $0.3-0.5 \mathrm{~cm}$; anthers ellipsoid, basifixed, lemon, inconspicuously two lobed. Nectar scales linear, $0.3-0.4 \mathrm{~cm}$, usually bifid, attached at ovary base. Pistils 4, obclavate, c. $0.8 \mathrm{~cm}$ long; ovary narrowly ovoid, green, c. $0.4 \mathrm{~cm}$ long; style conspicuous, c. $0.3 \mathrm{~cm}$, green to white, glabrous; stigma simple. Follicles narrowly ellipsoid, c. 0.7 $\mathrm{cm}$ long, glabrous, acrocidally dehiscent, fuscous, covered with the persistent, glandular, khaki corolla tube and calyx. Seeds numerous, ellipsoid, c. $1 \times 1 \mathrm{~mm}$, carunculate, testasulcate, fuscous to khaki.

Flowering \& fruiting: Flowering starts in October, peaks in December, and is followed by fruiting until February.

Habitat $\mathcal{E}$ distribution: Grows in rock crevices and along the edges of vertical cliffs of basalt rocky plateaus fully exposed to the sun; also found in rocky terrain on hilly slopes; between 700 and 1200 $\mathrm{m}$ above sea level. Kalanchoe olivacea is endemic to the Western Ghats: Maharashtra, Karnataka, Kerala and Tamil Nadu. The collections from Kerala: Palakad and Idukki districts (Sasidharan, 1999, 2002) and Tamil Nadu: Anamalai, Attakatti Hills and Coimbatore (Gamble, 1919; Singh et al., 2011), and Dindigul (Soosairaj et al., 2016) represent the southern most distribution of $K$. olivacea. However, its occurrence in Tirunelveli district (Manickam et al., 2008a, 2008b) is doubtful
- the illustration shows a glabrous inflorescence and flowers and the plant is therefore more likely to be referred to Kalanchoe floribunda var. glabra C.B.Clarke or K. bhidei.

Conservation status: The species might possibly occur elsewhere in Peninsular India, but on the data presently available, with a calculated area of occupancy of $20,000 \mathrm{~km}^{2}$, and extent of occurrence of $34,645.170 \mathrm{~km}^{2}$ in GEOCAT (Bachman et al., 2011), we evaluate the conservation status of K. olivacea as Least Concern (LC). No particular threats have been observed in the present studies.

Specimens examined: INDIA, Karnataka, Belgaum district, North of the Toorquary stage bungalow, s.d., Ritchie 330 [cited under K. brasiliensis by C.B. Clarke] (E!); Biligirirangan hills, Mysore district, 01.02.1971, R. Raghvendra Rao 1256 (JCB digital image!); Chikkaballpui, 08.01.1958, B.S. Parishwad 31100 (CAL!); Devagiribetta top, 14.07.1962, A.S. Rao 80021 (CAL!). Maharashtra district, Satara, Panchgani (along the cliff above the Bazar), s.d., s.coll. s.n. (BSI!) has an apparently recent, and certainly erroneous, anonymous pencil annotation 'used by Dalzell to describe K. olivacea', it is probably one of the R.K. Bhide collections from Panchgani and is certainly not Dalzell's; Ibid., s.d., L.D. Garade s.n. (BSI!); Pune district, Sinhagad (as 'Singhar'), 29.11.1905, annotated and cited by Cooke (1903) probably collected by Nairne (BSI!); Panchgani, W. Ghats, on Table Land, 11.1918, 1310 m, L.J. Sedgwick \& T.R.D. Bell 792/4694 (CAL!); Ibid., 12.1920, L.J. Sedgwick 7768 (K!); Panchgani, 20.11.2017, M.D. Nandikar 1760 (BSI!, CAL!, NGCPR!); Junnar, 24.07.2015, M.D. Nandikar s.n. (NGCPR!). Tamil Nadu, Coimbatore district, Top to Konnamalai, 15.01.1963, C.P. Sreemadhavan 392 (MH!); Dindigul district, Thonimalai, Kannivadi, 1370 m, 26.01.2015, S. Soosairaj \& P. Raja 2030 (RHT digital image!).

Notes: Kalanchoe olivacea can be recognized by its olive-coloured leaves, few-flowered, glandularhairy, compound cymes, distinctly obpyriform to pandurate buds, larger, lanceolate corolla lobes with acuminate to caudate apex. Besides its similarity to K. bhidei (Table 1), it also shares some characters, including glandular hairs, with $K$. laciniata, but that species can be differentiated by its pinnately dissected leaves and yellow flowers. 

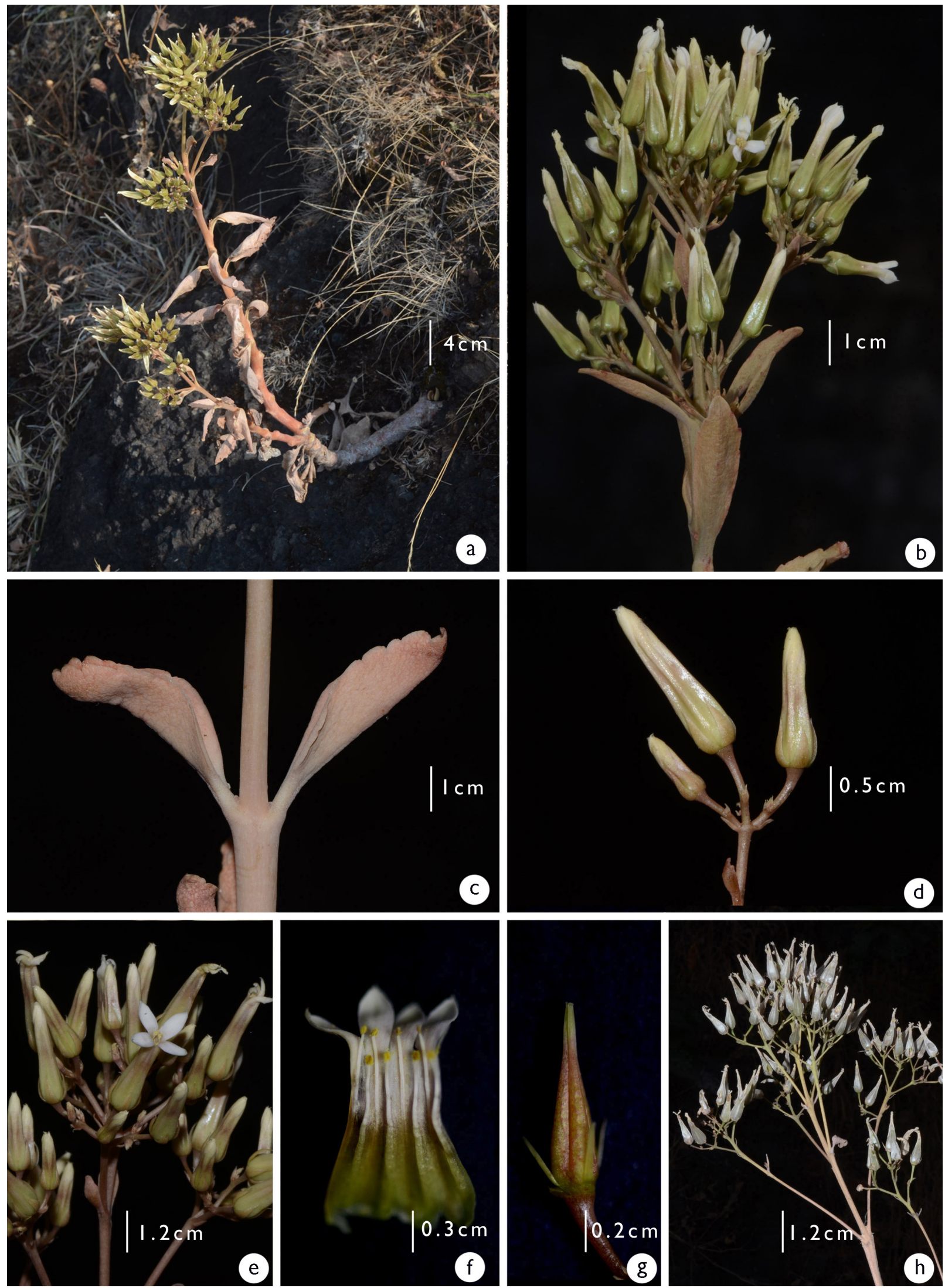

Fig. 4. Kalanchoe bhidei T.Cooke, a. Habitat; b. Habit; c. Leaves; d. Inflorescence; e. Flowers; f. Dissected flower with obdiplostemonous stamens, g. Pistil with linear nectar scales; h. Infructescence (Photographs: Mayur D. Nandikar). 


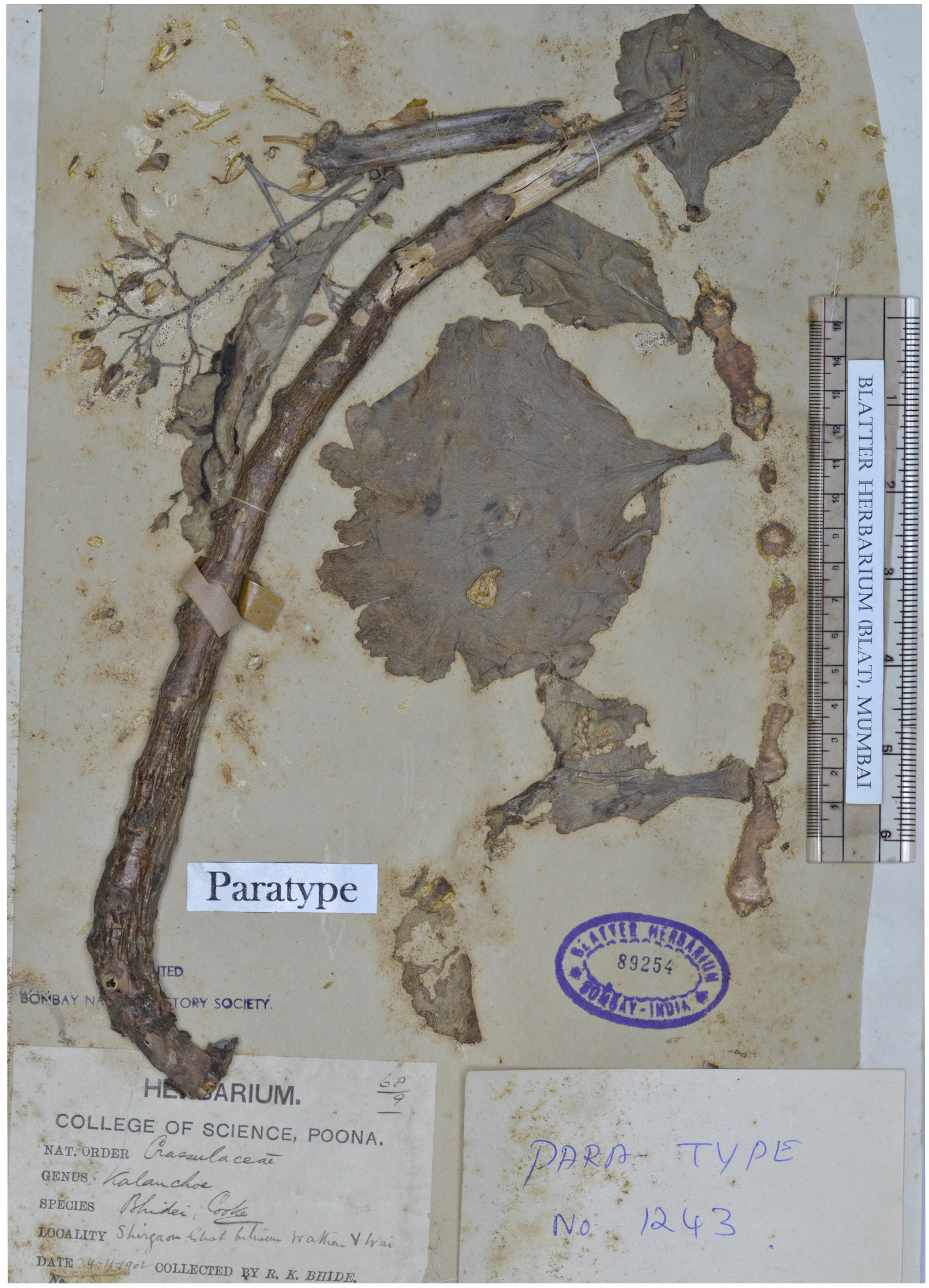

Fig.5. Lectotype of Kalanchoe bhidei T.Cooke (BLAT) 


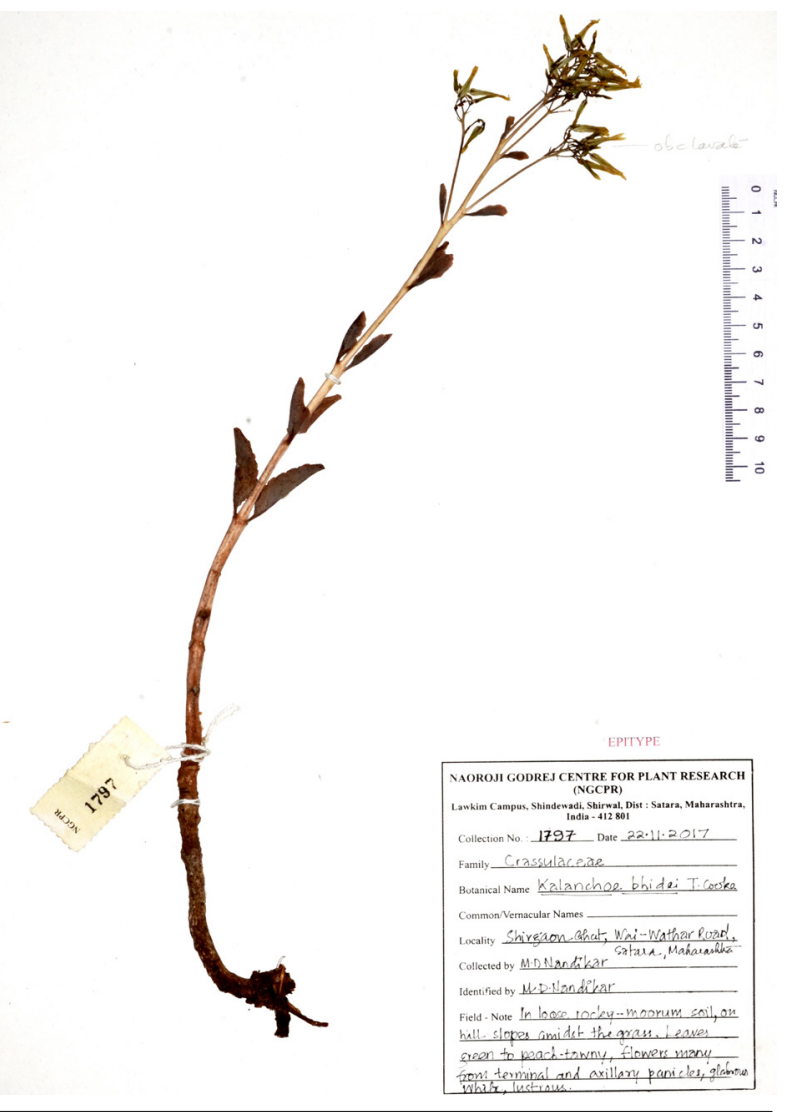

Fig.6. Epitype of Kalanchoe bhidei T.Cooke (CAL)

Kalanchoe bhidei T.Cooke, Fl. Bombay 1: 467. 1903. Lectotype (designated here): INDIA, Maharashtra, Shirgaon Ghat, between Wathar and Wai, 24.11.1902 R.K. Bhide s.n. [?1243] (BLAT!). Epitype (designated here): INDIA, Maharashtra, Satara district, Shirgaon Ghat, 22.11.2017, M.D. Nandikar 1797(CAL!; iso BSI!, NGCPR!) Figs. 4-6

Erect to decumbent perennial herbs, green to peach-tawny, solitary or sometimes tufted. Stems $30-100 \mathrm{~cm}$ tall, usually simple, occasionally branched, jointed, internodes lax, nodes cicatricose, peach-tawny, glabrous. Leaves caducous (stems leafless at fruiting), decussate, subsessile; lamina ovate to elliptic or oblanceolate, $2-12 \times 2-5 \mathrm{~cm}$, succulent, the proximal reduplicate, the distal conduplicate, glabrous, green to peach-tawny, base cuneate to attenuate margin crenate, distal leaves dentate to entire, apex rounded to obtuse in proximal leaves, acute in distal leaves. Inflorescence widely spreading, terminal and axillary, of many compound cymes; cymes 3-6-flowered, 5-9 cm long; peduncle 2-7 cm long, glabrous, stramineous; bracts fleshy, supra-axillary, subulate to falcate $c$.
$0.5 \times 0.2 \mathrm{~cm}$, glabrous, peach to coral; bracteoles similar to bracts, occasionally adhering to small, underdeveloped flowers. Flowers erect, pedicellate; pedicels $0.3-0.7 \mathrm{~cm}$ long, glabrous, buds obclavate, characteristic lustrous, angular-fluted. Calyx lobes free, narrowly ovate or trigonous, equal, c. $0.4 \times 0.1$ $\mathrm{cm}$, apex acuminate, glabrous, citrine to terracotta. Corolla $1.5-1.8 \mathrm{~cm}$ long, glabrous, obclavate with spreading corolla lobes; tube lustrous, distinctly angular-fluted, citrine to white; lobes white, spreading, narrowly ovate to lanceolate, c. $0.5 \times 0.2$ $\mathrm{cm}$, apex acute to acuminate. Stamens 8 , distinctly obdiplostemonous, the longer antipetalous, $c .1 \mathrm{~cm}$, exserted from corolla throat, the shorter between the corolla lobes, c. $0.8 \mathrm{~mm}$; filaments adherent to corolla tube, upper third free, filiform, $0.3-0.6 \mathrm{~cm}$; anthers ellipsoid, basifixed, lemon, inconspicuously two-lobed. Nectar scales linear to ensiform, c. 0.4 $\mathrm{cm}$ long, attached at ovary base. Pistils 4 (more laxly disposed than in K. olivacea), narrowly clavate, c. $1 \mathrm{~cm}$ long; ovary narrowly ovoid, c. $0.8 \mathrm{~cm}$ long, lemon, sprinkled with brick red; style gradually tapered from ovary, inconspicuous; stigma simple. Follicles narrowly ellipsoid, c. $1 \mathrm{~cm}$ long, glabrous, acrocidally dehiscent, fuscous-fawn, covered with persistent papery, ivory corolla tube and calyx. Seeds are numerous, ellipsoid, c. $1 \times 1 \mathrm{~mm}$, carunculate, testasulcate, fuscous to khaki.

\section{Flowering \& fruiting: As for K. olivacea.}

Habitat $\&$ distribution: Grows fully exposed to sun in open places, in loose, rocky 'moorum' (a soil type, comprised of small pieces of disintegrated rock or shale); on hilly slopes among grasses between 500 and $1200 \mathrm{~m}$ above sea level. Endemic to peninsular India: Maharashtra, Karnataka, Tamil Nadu (Gamble, 1919), and Andhra Pradesh (Chorghe et al., 2017).

Conservation status: Anthropogenic activities, especially road widening, have already led to the destruction of populations in a few of the localities where authors have previously observed K. bhidei. The other major threat comes from the native butterfly Talicada nyseus (Red Perriot), which completes its lifecycle entirely on members of the genus Kalanchoe (Singh, 2005) and has been observed feeding on K. bhidei. As K. bhidei is slow growing and its propagation, both sexual and vegetative, is limited, an infestation by Red Perriot is apparently causing damage to the sparse 
populations of this plant in their natural habitat. These observations point to a greater need for efforts towards the conservation of this species. With a calculated area of occupancy of 16,000 $\mathrm{km}^{2}$, and extent of occurrence of 122,100.774 $\mathrm{km}^{2}$ in GEOCAT (Bachman et al., 2011), its current conservation status is evaluated as Least Concern (LC).

Specimens examined: INDIA, Karnataka, Hassan district, Belavathalli state forest, 19.12.1968, C.J. Saldanha 11999 (JCB, digital image!); before Arsikere Town, 21.01.1970, C.J. Saldhana 16047 (E); Bourdalboore, 06.01.1970, C.J. Saldanha 15947 (K!); Chamarajanagar district, Billigirirangan Hills, 12.1938, Edward Batneo 2078 (K). Maharashtra,
Satara district, Pasarani Ghat, Wai to Panchgani, 03.02.2017, M.D. Nandikar 1384 (NGCPR); Nandgiri, Satara Road, 12.11.2017, M.D. Nandikar \& Rohini Shinde 1797 (NGCPR!). Tamil Nadu, Kodaikanal Ghat, Pulney Hills, 06.12.1898, Bourne 921? (MH00234653!); Vadakumalai, Vettakarankoil, Coimbatore, 1075 m, 08.01.1970, M.V. Viswanathan 352 (MH!).

Note: Only a handful of collections have been seen by the authors in various herbaria, and most of these are in poor condition with the exception of collections at $\mathrm{K}$ from Karnataka. The collection from the type locality, S.D. Deshpande 166455 (Deshpande \& Sharma, 1984), could not be found at BSI.

Table 1: Comparison of selected morphological characters of Kalanchoe olivacea and K. bhidei

\begin{tabular}{|c|c|c|}
\hline Characters & K. olivacea & K. bhidei \\
\hline Habit & $15-60 \mathrm{~cm}$ tall & $30-100 \mathrm{~cm}$ tall \\
\hline Stem & Many from the base, olive to tawny & Solitary or branched, peach-tawny \\
\hline Leaves & $\begin{array}{l}\text { Proximal sub-sessile, distal sessile; lamina } \\
\text { ovate to lanceolate or oblanceolate, } 1-10 \\
\times 0.5-4 \mathrm{~cm} \text {, acute to obtuse at apex, olive } \\
\text { to khaki or peach to terracotta }\end{array}$ & $\begin{array}{l}\text { All sub-sessile; lamina ovate to elliptic- } \\
\text { lanceolate, } 2-12 \times 2-5 \mathrm{~cm} \text {, acute to rounded } \\
\text { at apex in distal leaves, obtuse in proximal } \\
\text { leaves, green to peach-tawny }\end{array}$ \\
\hline Inflorescence & $\begin{array}{l}\text { Erect to patent, terminal and supra- } \\
\text { axillary, 3-6 compound cymes, each cyme } \\
\text { with 2-4 flowers, glandular hairy }\end{array}$ & $\begin{array}{l}\text { Spreading, terminal and axillary, many } \\
\text { compound cymes, each cyme with 3-6 } \\
\text { flowers, glabrous }\end{array}$ \\
\hline Peduncle & $\begin{array}{l}0.2-1.5 \mathrm{~cm} \text { long, glandular hairy, olive to } \\
\text { vinaceous }\end{array}$ & 2-7 cm long, glabrous, stramineous \\
\hline Flower buds & $\begin{array}{l}\text { Obpyriform to pandurate, terete convolute } \\
\text { and caudate to acuminate, glandular hairy }\end{array}$ & $\begin{array}{l}\text { Obclavate, angular-fluted, convolute, acute } \\
\text { to acuminate, lustrous-glabrous }\end{array}$ \\
\hline Calyx lobes & $\begin{array}{l}\text { Lanceolate, glandular hairy, pink to fawn } \\
\text { or olive }\end{array}$ & $\begin{array}{l}\text { Narrowly ovate to trigonus, glabrous, } \\
\text { citrine to terracotta }\end{array}$ \\
\hline Corolla & $\begin{array}{l}1.7-2 \mathrm{~cm} \text { long, tube obpyriform; lobes } \\
\text { lanceolate, acuminate to caudate, densely } \\
\text { to sparsely glandular without, sparsely } \\
\text { hairy within }\end{array}$ & $\begin{array}{l}1.5-1.8 \mathrm{~cm} \text { long, tube obclavate; lobes } \\
\text { narrowly ovate to lanceolate, acute to } \\
\text { acuminate, glaborus }\end{array}$ \\
\hline Stamens & Subequal, all included in corolla tube & $\begin{array}{l}\text { Unequal, the longer four exerted from } \\
\text { corolla tube }\end{array}$ \\
\hline Ovary & Narrowly ovoid, green & $\begin{array}{l}\text { Narrowly ovoid, lemon sprinkled with } \\
\text { brick red }\end{array}$ \\
\hline Style & Conspicuous & Inconspicuous \\
\hline
\end{tabular}


Hybridization is a common phenomenon between species of Kalanchoe as these may frequently be sympatric in the wild and hence numerous hybrid taxa have been described based on intermediate morphology (Descoings, 2003). K. cherukondensis Subba Rao \& Kumari (1978) is an apparently intermediate species between $K$. olivacea and $K$. bhidei, described based on a glabrous calyx and glandular corolla lobes. Kalanchoe (including Bryophllum) is a relatively large genus, most diverse in Tropical Africa and Madagascar with 144 species currently recognized (Mabberley, 2017). The Indian subcontinent has nine species (Singh et al., 2011) of which six are introduced and naturalized, while three are endemic and poorly documented. As no recent, complete monograph is available for the genus Kalanchoe, reliable species determination in the genus is confused and greatly in need of a revision (Descoings, 2003).

\section{Acknowledgements}

The first author wishes to thank Mr. Vijay M. Crishna, Director, Naoroji Godrej Centre for Plant Research (NGCPR) for offering research funding and laboratory facilities. We also wish to thank Clare Drinkell and Sally Dawson, Curators, Kew for the correspondence regarding the type, Dr. Rajendra Shinde, St. Xavier's College, Mumbai (BLAT), Sally King, Digitization Officer, Royal Botanic Garden Edinburgh (RBGE) for providing high resolution digital images of the type material, authorities at BSI, BLAT, CAL, DD, $\mathrm{E}, \mathrm{JCB}, \mathrm{K}$ and $\mathrm{MH}$ for allowing authors to study the specimens, Ms Priyanka, Ms. Durga and Mr. Kishor (NGCPR) for their voluntary help during the plant collections.

\section{Literature Cited}

ALMEIDA M.R. 1998. Flora of Maharashtra, Volume 2. Blatter Herbarium, St. Xavier's College, Mumbai, pp. 236-240.

BACHMAN S., MOAT J., HILL A.W., DE LA TORRE J. \& B. SCOTT 2011. Supporting Red List threat assessments with GEOCAT: Geospatial Conservation Assessment Tool. - In: SMITH, V. \& L. PENEV, (Eds.), e-Infrastructures for data publishing in biodiversity science. ZooKeys 150: 117-126.

CAMBESSÈDES J. 1829. Kalanchoe brasiliensis. In: SAINTHILAIRE A., JUSSIEU A.L. \& J. CAMBESSÈDES (Eds.), Flora Brasiliae Meridionalis, Volume 2. Apud A.
Belin Bibliopolam Paris. pp. 196.

CHORGHE A.R., RASINGAM L., PRASANNA P.V. \& M. SANKARA RAO 2017. Three new additions to the flora of Eastern Ghats. Nelumbo 59(1): 66-70.

CLARKE C.B. 1878. Kalanchoe. In: HOOKER J.D. (Ed.), Flora of British India, Volume 2. L. Reeve \& Co. London. pp. 414-416.

COOKE T. 1903. Flora of the Presidency of Bombay. Volume 1. Taylor \& Francis, London. pp. 467.

DALZELL N.A. \& A. GIBSON 1861. The Bombay flora, or, short descriptions of all the indigenous plants hitherto discovered in or near the Bombay presidency together with a supplement of introduced and naturalised species. Education Society's Press, Bombay. pp. 313.

DESCOINGS B. 2003. Kalanchoe. In: EGGLI U. (Ed.), IIlustrated Handbook of Succulent Plants: Crassulaceae. Springer-Verlag Berlin, Heidelberg \& New York. pp. 143.

DESHPANDE S. \& B.D. SHARMA 1984. A note of the topotypic occurrence of Kalanchoe bhidei Cooke (Crassulaceae) after eight decades. Bulletin of Botanical Survey of India 26 (3-4): 238-239.

GAMBLE J.S. 1919. Flora of the Presidency of Madras. Volume 1. Adlard and Son. London. pp. 449-51.

GANDHI K.N. 1976. Kalanchoe. In: SALDANHA C.J. \& D.H. NICOLSON (Eds.), Flora of Hassan District, Karnataka, India. Amerind Publishing Co. Pvt. Ltd., New Delhi. pp. 207-10.

GODBOLE A. \& S.K. DAS 2000. Crassulaceae. In: SINGH N.P. \& S. KARTHIKEYAN (Eds.), Flora of Maharashtra. Volume 1. Botanical Survey of India, Kolkata. pp. 842.

MABBERLEY D.J. 2017. Mabberley's plant-book, A portable dictionary of Plants, their classification and uses. Fourth edition, Cambridge University Press, Cambridge.

MANICKAM V.S., MURUGAN C., \& G.J. JOTHI 2008a. Flora of Tirunelveli Hills: Southern Western Ghats: Text. Bishen Singh Mahendrapal Singh, Dehradun.

MANICKAM V.S., MURUGAN C., JOTHI G.J. \& V. SUNDARESHAN 2008b. Flora of Tirunelveli Hills: Southern Western Ghats: Figures. Bishen Singh Mahendrapal Singh, Dehradun.

NOLTIE H.J. 2002. The Dapuri Drawings: Alexander Gibson and the Bombay Botanic Gardens. Royal Botanic Garden, Edinburgh. pp. 114, 115, 189

RAO R.R. \& B.A. RAZI 1981. A synoptic flora of Mysore District. Today \& Tomorrow's Printers and Publishers, New Delhi. pp. 427. 
RAO R.R. 1984. Crassulaceae. In: SALDANHA C.J. (Ed.), Flora of Karnataka. Volume 1. Oxford \& IBH Publishing Co., New Delhi. pp. 359.

SASIDHARAN N. 2002. Floristic studies in Parambikulam Wildlife Sanctuary. KFRI Research Report No. 246. Kerala Forest Research Institute, Thrissur.

SASIDHARAN N. 1999. Study on the flora of Chinnar Wildlife Sanctuary. KFRI Research Report No. 167. Kerala Forest Research Institute, Thrissur.

SHARMA B.D., SINGH N.P., RAGHAVAN R.S. \& U.R. DESHPANDE 1984. Flora of Karnataka. Analysis. Flora of India Series. Botanical Survey of India, Kolkata. pp. 98.

SINGH A.P. 2005. Initial colonization of Red Pierrot butterfly, Talicada nyseus nyseus Guerin (Lycaenidae) in the lower western Himalayas: An indicator of the changing environment. Current Science 89(1): 41-42.

SINGH N.B., BHATTACHARYYA U.C. \& B.P. UNIYAL 2011. Crassulaceae of India. Bishen Singh Mahendrapal Singh, Dehradun. pp. 54.

SOOSAIRAJ S., RAJA P., BALAGURU B. \& T. DONS 2016. Two additions to the flora of the Palni Hills, Southern India. Journal of Threatened Taxa 8(9): 92169220 .
SRINIVASAN S.R. 1983. Crassulaceae. In: NAIR N.C. \& A.N. HENRY (Eds.), Flora of Tamil Nadu, India: Analysis. Volume 1. Botanical Survey of India. Coimbatore.

STAFLEU F.A. \& R.S. COWAN 1976. Taxonomic Literature, Volume I: A-G. Second edition. Bohn, Scheltema and Holkema, Utrecht.

SUBBA RAO G.V. \& G.R. KUMARI 1978. A new species of Kalanchoe (Crassulaceae) from Andhra Pradesh. Bulletin of Botanical Survey of India 17(1-4): 177-179.

THE PLANT LIST 2013. Version 1.1. Published on the Internet; http://www.theplantlist.org/ (Accessed 07.01.2018).

TURLAND N.J., WIERSEMAJ. H., BARRIE F.R., GREUTER W., HAWKSWORTH D.L., HERENDEEN P.S., KNAPP S., KUSBER W.-H., LI D.-Z., MARHOLD K., MAY T.W., MCNEILL J., MONRO A.M., PRADO J., PRICE M.J. \& G.F. SMITH (Eds.) 2018. International Code of Nomenclature for algae, fungi, and plants (Shenzhen Code) adopted by the Nineteenth International Botanical Congress Shenzhen, China, July 2017. Regnum Vegetabile 159. Glashütten: Koeltz Botanical Books. DOI https://doi.org/10.12705/Code.2018. 